\title{
A Cultural Perspective of The Glass Cliff Phenomenon*
}

\section{Cam Uçurum Olgusuna Kültürel Bir Bakış}

\author{
Sebahattin YILDIZ1 \\ Mehmet Fatih VURAL ${ }^{2}$
}

\author{
https://orcid.org/0000-0001-7625-5358 \\ https://orcid.org/0000-0002-7822-6400
}

\begin{abstract}
The purpose of this paper is to reveal whether the phenomenon of the glass cliff, a concept related to gender discrimination, is valid in Turkey, where the level of femininity is relatively high. While the sampling method used was convenience sampling, the data collection tool was a questionnaire. The study was conducted with 240 managers in the business world and the appointment to a glass cliff position was assessed in terms of "suitability, leadership, and trust" dimensions. The findings revealed that managers did not opt for a female executive candidate as the CEO, using a scenario in which the "company performance is poor." Accordingly, in consideration of contextual fundamentals, it can be suggested that the concept of the glass cliff, a term coined by psychologists Ryan and Haslam in the United Kingdom, where masculinity is predominant, may not be valid for Turkey, where the level of masculinity is relatively low.
\end{abstract}

Keywords: Career management, gender, gender discrimination, glass cliff, glass ceiling, Turkish culture.

\section{Introduction}

Women who seek leadership positions are frequently faced with barriers that hinder their progress (Mulcahy and Linehan, 2014: 425). Factors that prevent women from being promoted to management positions or impair their career development include stereotypes, lack of mentorship, inability to become involved in networks, discrimination in the workplace, family issues and becoming one's own boss (Dzanic, 2009: 9-10).

In contrast to the concept of the glass ceiling, which refers to the subtle, i.e. invisible (glass) barriers

\section{Öz}

Bu çalışmanın amacı cinsiyet ayrımcılığıyla ilgili güncel bir kavram olan cam uçurum fenomeninin dişillik seviyesi kısmen yüksek olan Türkiye'de geçerli olup olmadığını araştırmaktır. Örnekleme metodu kolayda örnekleme iken veri toplama aracı ankettir. Çalışma iş dünyasındaki 240 yöneticiye uygulanmıştır ve bir cam uçurum pozisyonuna atamada "uygunluk, liderlik ve güven" boyutları dikkate alınmıştır. Bulgular göstermiştir ki yöneticiler şirket performansının kötü olduğu bir senaryoda, kadın yönetici adayını CEO olarak tercih etmemişlerdir. Buna göre bağlamsal temeller dikkate alındığında erilliğin baskın olduğu Birleşik Krallıkta psikolog olan Ryan ve Haslam tarafından ortaya atılan cam uçurum kavramının erillik seviyesinin kısmen düşük olduğu Türkiye'de geçerli olamayabileceği söylenebilir.

Keywords: Kariyer yönetimi, toplumsal cinsiyet, cinsiyet ayrımcilığı, cam uçurum, cam tavan, Türk kültürü.

\footnotetext{
* The manuscript is composed out of master thesis of Mehmet Fatih VURAL.
} 
concept, obtaining a successful leadership position that would be particularly challenging and demanding for women, as they may be preferred for failing positions, contributes to the negative perceptions of their leadership ability (Chambers, 2011: ii).

In an investigation of 100 listed companies on the British stock exchange, in a study analyzing the conditions under which women are assigned to leadership positions and the outcomes of such appointments on company performance, Judge (2003) revealed that companies with women on their executive boards generally faced poor market performance. The study claimed that the ability of women to smash the glass ceiling and progress to the executive of boards of companies in the country was rather detrimental to the companies' performance and market value. On the other hand, in emphasizing that poor company performance and adverse circumstances lead to the appointment of women to leadership positions, rather than vice versa, Ryan and Haslam (2005) proposed the concept of a glass cliff, referring to appointments to management positions under adverse circumstances, to be the cause of poor company performance.

An evaluation of the situation in Turkey from a cultural standpoint (Hofstede, Hofstede and Minkov, 2010) reveals that while Turkey has relatively lower masculinity levels (index $=45$ for Turkey), countries such as the United Kingdom, where the glass cliff phenomenon is observed, have higher masculinity levels (index $=66$ for the UK). Studies into this phenomenon have on the whole been carried out in countries such as the United Kingdom and the United States, where patriarchal roles and characteristics such as power, control and success are mostly in the hands of men. In cultures such as Turkey, where femininity is more prevalent, the glass cliff phenomenon may not be applicable, because in cultures where femininity is more dominant, management appointments differ only slightly between women and men. For this reason, the appointment to a managerial role in such countries follows a more egalitarian approach. Whether or not this is also applicable in Asian and Middle Eastern countries has yet to be investigated. The reasons for carrying out this study in Turkey is based on the fact that no study has been carried out to date on this subject in the Turkish context, and unlike the other studies, Turkey has a feminine culture among the cultural dimensions determined by Hofstede, and that the employment rate of women in Turkey is low (28\%), and much lower in management positions.
The purpose of this study is to identify whether or not the concept of the glass cliff, which can be considered as a form of gender discrimination, is prevalent in Turkey. The investigation of whether the participants opted for women as CEO candidates in a scenario in which company performance is poor within the context of Turkey would be the main contribution of this study. In addition to this, an attempt will be made to determine how the glass cliff phenomenon differs within different cultures, and also whether the phenomenon can actually be applied to different cultures. At the same time, the study will attempt to answer the question of whether it is men or women who actually steer women towards the "edge of the cliff" in cases and in countries where the glass cliff phenomenon exists. In literature, the glass cliff phenomenon is related to the "leadership ability" and "suitability" dimensions (Haslam and Ryan, 2008), while in the present study, the "trust" dimension (Chambers, 2011) was also taken into consideration, in addition to these two other dimensions, as this contributes to a more comprehensive and novel approach to the glass cliff concept.

In the glass cliff concept, which can be defined as a tool for gender discrimination, women are set up to fail by being appointed to upper management positions in times of low performance in the company. In this regard, the phenomenon can be considered as a barrier to career possession, as expressed by second-wave feminists. This pioneering article will contribute mainly to the discussion of whether the glass cliff phenomenon, as a form of gender discrimination, is a valid concept by examining it within the cultural context.

\section{Theoretical basis of gender discrimination}

In general, the theoretical basis of gender discrimination may be examined in terms of (1) theories of gender, and (2) feminist theories (Başak, 2013: 222-232). While the term "sex" refers to the biological and physiological characteristics of individuals as men or women, gender refers to the socio-cultural constructions, perceptions and ideas of, and meanings attributed to, sexual difference rather than biological differences, and to the expectations of how we should behave (Broadbridge and Simpson, 2011: 470). The term "gender" highlights the socio-cultural aspects of the relationship between men and women, such as parenting methods and the uneven division of labor within the household, which cannot be explained by sex (Giddens, 2012: 505). 
Feminist theories on the social role and status of women have emerged around the concepts of rights and equality (the discourse of first-wave feminism), and today it has been transformed into a liberation movement in which the subordination and oppression of women in both the public and private sphere on the basis of gender are called into question (Alican, 2008: 29). Second-wave feminist theories (cultural, radical and Marxist), on the other hand, underline that even though men and women have equal rights, negative discrimination against women persists as a result of cultural and patriarchal constructs.

In Turkey, Article 10 of the Constitution of the Republic of Turkey stipulates that "men and women have equal rights" (www.tbmm.gov.tr, Access Date: 13.05.2016), and Article 5 of the Labor Law states that "discrimination based on sex shall be prohibited in business relationships" (www.tbmm.gov.tr, Access Date: 13.05.2016). Aside from the principle, "No women, regardless of her age, shall be employed in underground work (such as the laying of cables, sewage and tunnel construction) at any time" (www.ilo.org, Access Date: 23.03.2016) laid down in Article 2 of ILO Convention No. 45 entitled "Underground Work (Women)", which has been endorsed by Turkey, women are entitled to do any job. In this regard, rather than legal barriers, it is apparent that the impediments faced by women in their working lives are related to the patriarchal structure of society. In this study, the phenomenon of glass cliff, as a gender discrimination issue, was examined in the context of second-wave feminist theories.

\section{Femininity and masculinity}

Masculinity and femininity, which are among the Hofstede's cultural dimensions, are related to gender roles. Men, in short, are supposed to be assertive, competitive, and tough while women are supposed to be more concerned with taking care of the home and the children, and they are compassionate people. A society is referred to as "masculine" when emotional gender roles are clearly distinct: men are supposed to be assertive, tough, and focused on material success, whereas women are supposed to be more modest, tender and concerned with quality of life. There are key differences between feminine and masculine societies. For example, while relationships and quality of life are important in feminine societies, challenges, earnings, recognition and advancement are important in masculine societies. While both men and women should be modest in a feminine society, men should be assertive, ambitious and tough in a masculine society. While women and men teach young children in feminine society, it is a woman's task teach young children in a masculine society (Hofstede, Hofstede and Minkov, 2010).

In a feminine society, one attribute of the national culture attribute is that little differentiation is made between male and female roles, and women are treated as the equals of men in all aspects of society. A high femininity rating doesn't mean that a culture emphasizes feminine roles, in that it is equality that is emphasized between men and women. A high masculinity rating in a culture indicates that separate roles are assigned to men and women, with men dominating society (Robbins and Judge, 2013). In this respect, the glass cliff phenomenon that is applicable in cultures where the masculinity is high may not be applicable in other cultures where femininity is high.

\section{Concepts related to gender discrimination in organizations}

Several concepts highlighting the gender discrimination experienced by women in the corporate culture, such as the glass ceiling, the glass elevator, the glass escalator, tokenism, the double bind, the glass wall, the glass labyrinth, and of course, the glass cliff, are discussed within the context of gender and feminist theories. While the glass ceiling refers to an invisible barrier that prevents women from advancing beyond a certain level in a corporate hierarchy (Sabharwal, 2013: 400), the glass cliff refers to the tendency to appoint women to riskier management positions where the potential for making mistakes is relatively high (Ryan and Haslam, 2005: 81). Glass elevator or glass escalator, in contrast, refers structures and practices that lead men to advance faster, particularly in businesses where women are predominant (Williams, 1992: 253; Budig, 2002: 258), whereas the glass wall refers to invisible obstacles that restrict the horizontal mobility of women on the way up to senior management, and keep them in certain types of activities/sector segments (Sabharwal, 2013: 399). The glass labyrinth is used to refer to all of the obstacles faced by women that prevent them from reaching appropriate positions throughout their careers (Eagly and Carli, 2007), while tokenism refers to the policy of showcasing ostensible efforts, promotions or gestures, particularly among women and minority groups (Kanter, 1977). Finally, double bind refers to a situation in which a female executive cannot be successful, regardless of how she acts, due to her being trapped 
between two conflicting demands (Lamsa, Jyrkinen and Heikkien, 2012).

The presence of so many concepts suggests that gender discrimination is still an important problem. Although the concepts that deal with these problems from different perspectives lead to confusion, there are differences between them. In this study, we have focused on glass cliff phenomenon, as a much-discussed and interesting topic in literature.

\section{Glass cliff}

Ryan and Haslam (2005) first coined the term "glass cliff" to refer to an adverse situation for women, introducing the concept as a criticism against Judge's (2003) article entitled "Women on Board: Help or Hindrance?" in The Times. (Ryan and Haslam, 2005: 82). Judge (2003) examined the situation in 100 large companies in the United Kingdom in which women had been appointed to management positions, and revealed that the performances of these companies tended to deteriorate when compared to those that only had men on their executive boards. In contrast to Judge (2003), who claimed that British companies would be better off without the women they had appointed to their boards, suggesting that company performances would deteriorate in cases where they appointed women, Ryan and Haslam (2005: 81-90) analyzed the performances of 100 listed companies in the United Kingdom before and after the appointment of men and women to their executive boards, and showed that appointments varied in terms of gender and context (organizational condition). While companies that appointed men to their boards experienced stability and growth both before and after these appointments, it was observed that most of the companies that appointed women to management positions were less successful and experienced financial difficulties before promoting women. In this regard, it can be understood that the glass cliff concept is used to define the appointment of many women who break through the glass ceiling to riskier positions (Haslam and Ryan, 2008: 531). Such positions neither improve the status of women nor eliminate the prejudices towards women on boards, but rather foster negative stereotypes and discrimination.

The categories used to define the glass cliff are sexism (gender barriers), preferability within groups (man's work), sacrificing women and laying the responsibility on others (seeking a scapegoat), lack of opportunity (women accept risky positions), lack of communication networks and support (material, intellectual and emotional support), gender stereotypes (ability to hedge risk, coping with failure, being more competent under risky situations), displaying equality (appointing women to riskier positions to create the impression that no glass ceiling exists), factors related to the company, (doing something outside the box, as a last hope and appointing women to improve a company's image), and denying the phenomenon (questioning the existence of the glass cliff, claiming that the "best candidate for the position was appointed") (Ryan et al., 2007: 188-191).

The glass cliff is neither universal nor inevitable (Ryan and Haslam, 2009). The role of men in leadership positions, or the reason for the glass cliff, may be explained by means of several much-debated stereotypes. These stereotypes are "think manager-think male" (the task of managers is masculine, and so more suitable for men, and requires emotional balance, aggressiveness, self-confidence, competitiveness and objectivity); social role (while men behave agentically, in other words, aggressively, decisively, self-confidently, independently and dominantly, women behave socially, namely, in a polite, compassionate, empathetic and emotional way); and role overlapping (explains the prejudices towards women in social and leadership roles. "An inconsistency arises when there is a conflict between the social roles women are expected to fulfill and the requirements of leadership roles") (Sabharwal, 2013: 399).

Female leaders who manage to break through the glass ceiling are assigned to positions on the glass cliff, and so must work under stress in these risky positions at times when company performance is poor. Women exposed to such stresses and pressures are subjected to criticism and intimidation for not doing their jobs properly, and eventually, organizational disidentification takes place. In the end, having shown that women cannot be good leaders, male managers who are not satisfied with the leadership of women force them onto a career plateau, causing them to return to less rewarding positions in terms of prestige and remuneration, or even to leave the organization (Ryan and Haslam, 2006: 46).

The reactions of women and men to the glass cliff in different parts of the world are clearly different. While women accept the existence of the glass cliff, and perceive injustice, sexism, inequality opportunity and barriers, men tend to question the validity of the glass cliff or underestimate it, defining it in more moderate 
terms, and associate it with suitability for challenging leadership tasks, the need to make strategic decisions and company factors that are unrelated to gender (Ryan et al., 2007). The probability of women falling off the glass cliff is lower when they have "influence over policy-making decisions, perceive empowerment, experience organizational justice, and when they are satisfied with their work-life balance" (Sabharwal, 2013: 400).

\section{Glass cliff in literature}

Several papers published in the British Journal of Management have addressed the ongoing debates on this subject. Initially, Judge (2003) argued that the performance of companies that appoint women to their boards tends to be poorer than those that have all-male boards. Criticizing this argument, Ryan and Haslam (2005) revealed that the companies that had appointed women to management positions had already been performing poorly before the appointment, and used the term "glass cliff" for the first time to refer to such positions. Adams, Gupta and Leeth, (2009), in turn, claimed that there is no glass cliff, as companies appoint women to CEO positions when their financial performances are strong, including the "period before the appointment". However, publishing a theoretical article highlighting that it is not easy to measure the glass cliff, and that the glass cliff cannot be identified merely by referring to financial performance, Ryan and Haslam (2009) criticized the results of Adams et al's (2009) study. In a further criticism of Adams et al's (2009) study, Haslam, Ryan, Kulich, Trojanowski and Atkins (2010) identified a negative correlation between the representation of women on executive boards and subjective, market-based performance indicators (Tobin's Q), thus confirming the validity of the glass cliff. Yet in the same study, Haslam et al. (2010) stated that the glass cliff theory could not be supported, as there was no correlation between the representation of women on boards and objective accounting performance indicators (ROA, ROE). On the other hand, Mulcahy and Linehan (2014) concluded that as the precarious position of listed companies increases, the probability of the over-representation of women on boards increases, thus supporting the glass cliff phenomenon.

Moreover, further articles have been published on the measurement of glass cliff appointments based on perception. According to Haslam and Ryan's study (2008, Study 1), graduates of business management schools perceived female candidates to be preferable to male candidates for leadership positions (in terms of leadership ability and suitability) when the company is performing poorly, while in another study by Haslam and Ryan (2008, Study 2), college students opted for the female candidate for the leadership position of a large-scale music festival when the popularity of the festival was falling and the risk of failure was rising. In a third study by Haslam and Ryan (2008, Study 3), it was revealed that businessmen/women perceived female candidates as more suitable for the finance manager position when the company was underperforming. Moreover, according to Ryan, Haslam, and Kulich (2010), political science students selected the female presidential candidate to contest hard-to-win seats (when the majority of seats were held by the opposition). Accordingly, based on the assumption that the ideal manager type would be women in times of poor company performance, Ryan et al. (2011, Study 2) suggested that a "think crisis-think female" association is at work. According to Uyar (2011), when company performance is deteriorating, the "female candidate was perceived as more suitable and capable for leadership than the male candidate". According to Ashby et al. (2007), law students preferred female attorneys for riskier rather than relatively easy cases. Ryan et al. (2011, Study 3) highlighted that women are promoted in times of poor performance, since there is little faith that they can improve performance and are not perceived as good managers, and they will be blamed for the organizational failure.

In previous literature, the glass cliff phenomenon is not addressed solely from a gender discrimination perspective, but also from a racial/ethnic discrimination perspective. For instance, white, rather than black and minority, head coaches were promoted to teams with the potential break a winning record in the basketball league (Cook and Glass, 2013). Similarly, even though black and ethnic minority candidates performed worse than their white counterparts in the 2001, 2005 and 2010 elections in the United Kingdom, this underperformance was explained by the lower winnability of black and ethnic minority candidates, such that the opposition candidate held a seat with a considerably larger majority compared to white candidates' opponents. In other words, the seats contested by black and ethnic minority candidates were harder to win (Kulich, Ryan, and Haslam, 2014). Regardless of the above, the present study addresses the glass cliff phenomenon solely as one associated with gender discrimination. 
The following hypotheses were developed on the basis of the theoretical framework described above and from empirical studies in literature.

Hypotheses 1: The preference level in favor of a manager candidate varies according to "company performance".

Hypotheses 1a: The preference level in favor of a male candidate varies according to "company performance". (Do participants show a greater preference for male manager candidates under positive circumstances than under adverse circumstances?)

Hypotheses $\mathbf{1 b}$ : The preference level in favor of a female candidate varies according to "company performance". (Do participants have a greater preference for female manager candidates under adverse circumstances than under positive circumstances?)

Based on the assumption that women could be exposed to the glass cliff by men under patriarchal social structures and in male-dominant cultures, the following hypothesis, which "has not been investigated in literature, and has only been proposed as an alternative research question" was suggested in order "to fill the gap":

Hypotheses 2: The preference for female manager candidates for senior manager positions in times of poor performance varies according to "the gender of the participants." (Do male participants have a greater preference for female manager candidates than the female participants? In other words, do they lead female candidates to the glass cliff?)

\section{Method}

\section{Sample}

The phenomenon of the glass cliff in literature has been studied on a sample of managers in a number of studies. This study's sample comprised 240 managers, of which $30(\% 12,5)$ were upper level managers, 164 $(\% 68,3)$ were middle level managers and $46(\% 19,2)$ were first level manages; of which $138(\% 57,5)$ were in service sector (banking, telekominication) and $102(\% 42,5)$ were in manufacturing sector (defense, automotive, iron and steel); of which 129 (54\%) were female and 111 (46\%) were male; of which $33(\% 13,8)$ were below 25 age, $116(\% 48,3)$ were between 26 and 35 age, and $91(\% 37,9)$ were over 36 age, the mean age was 36; of which $23(\% 9,6)$ were below 1 year experience, $115(\% 47,9)$ were between 1 and 10 year experience and $102(\% 42,5)$ were over 11 year experience.

While 133 questionnaires were collected via face to face, 107 questionnaires were collected via e-mail in Istanbul, Ankara, Konya and Ardahan, Turkey.

\section{Measurement}

The data collection tool was a questionnaire. In the glass cliff appointment, three dimensions were used: suitability, leadership ability and trust. It was measured with nine statements. The six statements on suitability ( 3 items) and leadership ability (3 items) dimensions were developed by Ryan and Haslam (2006), and adapted into Turkish by Uyar (2011), while the three items in the trust dimension were, in turn, developed by Chambers (2011) and adapted into Turkish by the authors. A 5-point Likert scale was used in the measurements and a convenience sampling method was preferred because of basing on the voluntary participation of the respondents.

The gender of the manager candidate (female or male), the gender of the participant (female or male) and the company performance (good or poor), all of which are factors affecting the glass cliff, were taken as the independent variables in the research. The dependent variable, on the other hand, was the glass cliff phenomenon, which implies the appointment (preferential assignment) of a manager candidate according to suitability, leadership and trust dimensions.

The two performance scenarios in the research, being good (golden period) and poor (critical period), were designed in relation to company performance. The scenarios were adapted from a news story about a company whose CEO had recently resigned. The participants were asked to evaluate, i.e. appoint, one of the two CEO candidates (a female and a male), whose CVs were exactly the same, considering their suitability, leadership and trust dimensions. For both candidates, who differed only in terms of gender, the CV of the former CEO of a reputable company was used. The questionnaire was completed by the participants using step-by-step briefings given in consultation with the researcher in a classroom setting.

\section{Dimensions of the glass cliff}

In literature, it can be observed that two methods are used to indicate a preference (assignment) of managers for glass cliff positions. In the first method, the participants were expected to answer the question "Which do you prefer, male or female candidates?" 
In the second method, participants were asked to evaluate a number of dimensions (variables) in indicating a preference. In order to define how women are driven into to "senior management positions in a manipulative manner" in organizations during times of crisis, in other words, to explain how they are led to the glass cliff, the dimensions of suitability, leadership ability and trust have been used in literature (Haslam and Ryan, 2008; Dzanic, 2009; Ak Kurt, 2011; Chambers, 2011; Uyar, 2011). In this study, suitability and leadership ability (Haslam and Ryan, 2008), as well as trust in a manager (Chambers, 2011: 7) are taken into consideration in the promotion of an individual to a senior management position. We prefer to use the second method, being much more objective in the evaluation of manager candidates, in that it takes into account their managerial characteristics rather than being based on a general evaluation. The phenomenon of the glass cliff is measured based on secondary data, or perceptually, in literature. A perceptual measurement is also performed in this study. We used three dimensions to be able to make better decisions as regards preference by bringing the suitability, leadership ability and trust variables together, all of which have been used and accepted in the literature, but in different studies.

\section{Collection and analysis of data}

The data collection process was as follows: (1) Reading the resumes of CEO candidates (one male, one female), (2) reading the announcement of the company at which the CEO is to be employed, (3) reading the positive performance scenario, (4) asking the participants to evaluate the male candidate according to the positive scenario, (5) asking the participants to evaluate the female candidate according to the positive scenario, (6) reading the negative performance scenario, (7) asking the participants to evaluate the male candidate according to the negative scenario, (8) asking the participants to evaluate the female candidate according to the negative scenario.

The data was analyzed using SPSS 20 package software. In order to identify "the differences in appointments to the CEO position" in terms of the gender of the participants (female or male), the gender of manager candidates (female or male) and the company performance, $\mathrm{t}$-tests were applied.

\section{Findings}

\section{Means, Validity and Reliability Analyses}

The study comprised 240 managers, of which 129 (54\%) were female and 111 (46\%) were male; while the mean age was 36 . An exploratory factor analysis was conducted in relation to the validity analysis of scales (construct validity), and the internal consistency (Cronbach's alpha) coefficient was taken into consideration for the reliability analysis. An increase in the glass cliff was measured with nine statements as a single dimension. Based on the scores presented in Table 1, the scales can be considered valid and reliable (Hair et al., 1995; Nunnally, 1978).

\section{Hypothesis Tests}

The following findings were obtained from the analyses regarding the hypotheses (along with the research questions).

The preference level for male manager candidate varied according to "company performance" $(p<.05)$. The participants showed a greater preference for male manager candidates in times of good performance, as opposed to periods of poor performance. In other words, the preference for male manager candidates declined in times of poor performance. Accordingly, Hypotheses 1a was accepted (Table 2).

Table 1: Information on the scales of managers

\begin{tabular}{llllll}
\hline Candidate / Performance Period Scales & KMO & Bartlett's & Explained & Reliability & Mean \\
& & Test (sig) & Variance & \\
\hline Male Candidate, Good Performance & .843 & .000 & 52.3 & .88 & 3.64 \\
Male Candidate, Poor Performance & .897 & .000 & 60.7 & .91 & 3.45 \\
Female Candidate, Good Performance & .880 & .000 & 61.2 & .92 & 3.61 \\
Female Candidate, Poor Performance & .887 & .000 & 68.4 & .94 & 3.49 \\
\hline
\end{tabular}


The preference level for the female manager candidate varied according to "company performan$c^{\prime \prime}(p<.05)$. Therefore, Hypotheses $1 \mathrm{~b}$ was accepted (Table 3). While participants were expected to show a greater preference for female manager candidates in times of poor performance, according to this finding, the preference for female manager candidate declined considerably in this period when compared to the period when company performance was good. In other words, the preference for female manager candidates was higher in times of good performance. This was a situation, which did not support the glass cliff phenomenon. This result could be explained by the femininity culture of Turkey. The reason underlying this finding can be discussed as follow: The glass cliff is valid in where masculinity is predominant but in Turkey, according to Hofstede's culture dimensions, the level of masculinity is relatively low (index $=45$ for Turkey). (www.hofstede-insight.com/country/ turkey). In masculinity cultures, patriarchal roles and characteristics such as power, control and success are mostly in the hands of men. Therefore, men perceive women as competitors for management positions and they lead women into cliffs because they see them as competing people. Besides, men want to see women as responsible for failure (seeking a scapegoat). But in Turkey that the level of masculinity is low, women may not have been dragged into the glass cliff because women are not perceived as people who will be competition for men.

In times of poor performance, the preference for a female manager candidate for the senior manager position varied according to "the gender of the participant" $(p<.05)$. Therefore, Hypotheses 2 was accepted (Table 4). While male participants were expected to have a higher preference for the female manager candidate, it was the female participants that had a higher preference for the female manager candidate in times of poor company performance. Contrary to the general belief (that men steer women towards the glass cliff), it was the female participants who tricked the female manager candidate by forcing her to take the senior manager position in times of crisis, hence leading her to the glass cliff. This result may be attributed to the "Queen Bee Syndrome" (Staines, Tavris, and Jayaratne, 1974). In times of poor performance, it is the female participants rather than male participants who showed a greater preference for female candidates in upper management positions. Therefore, it was women rather than men who, in this particular context, pushed women towards the glass cliff.

Table 2: Paired samples $t$-test results regarding the preferability of the male candidate according to performance period

\begin{tabular}{lccccc}
\hline Performance & N & Mean & Good Performance & T & Sig. (2 tailed) \\
\hline Good Performance & 240 & 3.6243 & - Poor Performance & \\
Poor Performance & 240 & 3.4425 & 0.18178 & 4.471 & .000 \\
\hline
\end{tabular}

Table 3: Paired samples $t$-test results regarding the preferability of the female candidate according to performance period

\begin{tabular}{lccccc}
\hline Performance & N & Mean & Good Performance & T & Sig. (2 tailed) \\
\hline Good Performance & 240 & 3.6080 & - Poor Performance & & .008 \\
Poor Performance & 240 & 3.4944 & 0.11368 & 2.677 & \\
\hline
\end{tabular}

Table 4: Independent samples $t$-test results regarding the preferability of the female candidate in times of poor performance

\begin{tabular}{cccccccc}
\hline $\begin{array}{c}\text { Candidate/ } \\
\text { Performance }\end{array}$ & $\begin{array}{c}\text { Participant's } \\
\text { Gender }\end{array}$ & $\mathrm{N}$ & Mean & Std. Devation & $\begin{array}{c}\text { Mean } \\
\text { Difference }\end{array}$ & $\mathrm{t}$ & $\mathrm{p}$ \\
\hline $\begin{array}{c}\text { Female } \\
\begin{array}{c}\text { Candidate, Poor } \\
\text { Performance }\end{array}\end{array}$ & Female & 129 & 3.6129 & .81401 & 0.25634 & 2.366 & 0.019 \\
\hline
\end{tabular}


In the above an Alyses, the glass cliff phenomenon when choosing preferences for the senior manager position was measured as a single dimension, while more detailed analyses took the sub-dimensions into consideration. According to the results of the deeper analyses, carried out taking the "ability, leadership, and trust" dimensions into consideration, women perceived the female candidate to be significantly more capable, suitable for the leadership role and trustworthy in times of poor performance than men (in other words, they were more disposed to leading the female candidate to the glass cliff). Surprisingly, no difference was found between the female and male participants with regards to the perception of the male candidate as capable, suitable for the leadership role and trustworthy in times of poor performance.

\section{Discussion}

While there is a perceived mismatch between leadership and stereotypes about women (think leader-think male), there is a perceived congruence between crisis management and stereotypes about women (think crisis-think female) (Ryan et al., 2007: 185). In other words, women are perceived to be good at crisis management, and are assumed to be able to cope with stress, traits that actually lead them into manipulative glass cliff positions. In this study, the phenomenon of the glass cliff has been examined in the context of second-wave feminist theories. It has been stated that there are the barriers which are related to culture and stereotypes, although there are no legal obstacles preventing women from being promoted to upper management positions according to this theory.

The participants had a greater preference for male manager candidates in times of good performance when compared to periods of poor performance. In other words, the preference for male manager candidates declined in times of poor performance. This finding is in line with Ryan and Haslam (2005), Ashby et al. (2007), Haslam et al. (2010), Ryan et al. (2011), Bruckmüller and Branscombe (2010), and Uyar (2011). It was observed that, as in the case of the United States and the United Kingdom, Turkey is also a country where male manager candidates are largely preferred during positive times. The reason underlying this finding can be discussed as follow: Men firstly come to mind when it is thought of who should be the manager in corporations. Men are not as sentimental as women, they decide quickly from women and men can clash more than women when there is a dispute. The task of managers requires emotional balance, aggressiveness, self-confidence, competitiveness and objectivity. While men behave agentically, in other words, aggressively, decisively, self-confidently, independently and dominantly, women behave socially, namely, in a polite, compassionate, empathetic and emotional way. Therefore the task of managers is masculine, and so more suitable for men, expecially in positive performance situation than negative performance situation (Discussion 1).

The participants did not demonstrate a greater preference for female candidates in times of poor performance rather than in times of good performance of company, and this finding is contrary to the glass cliff phenomenon, but in line with Ak Kurt (2011). In the countries that masculinity is high, men see women as rivals and they don't want women to succeed because they lose their decision-making authority. Therefore men choose women as managers in negative performance periods, in other words, they push women to cliff. Since challenges, earnings, recognition and advancement are important and men should be assertive, ambitious and tough in masculine societies. But in Turkey, women may not be dragged into the cliff because they are not perceived as men to competing people. Since relationships and quality of life are important in feminine societies and both men and women should be modest in a feminine society. Additionally, there are few differences between male and female roles in feminine cultures, where women and men are treated equally. Modesty and quality of life are high on the agenda, rather than features such as challenge, recognition and ambition. The employment rate of women in Turkey is quite low, at 30 percent thus it can say that men do not perceive women as competitors for upper management positions and do not push into them the glass cliff as a career barrier. If we look at this finding from another perspective, because men don't see women as responsible for failure (seeking a scapegoat), they don't push women to cliff. (Discussion 2).

The female participants had a higher preference for female manager candidates in times of poor performance than the male participants, and this finding is in line with Hunt-Earle (2012). Hunt-Early (2012), in paper named "Falling Over a Glass Cliff: a Study of the Recruitment of Women to Leadership Roles in Troubled Enterprises" revealed that women recruiters preferred female candidates for high-risk roles. The view that 
women are pushed towards the glass cliff by men in times of negative performance in a company has been shown to be erroneous, as women are observed to be pushed into risky positions by other women, rather than by men. This finding contradicts the patriarchal perception and the glass cliff phenomenon, and may be explained by the lack of opportunities offered to women. It could also be suggested that women accept precarious positions as they perceive senior manager positions to be an opportunity, even though they are risky. Based on these findings, the following can be said of the glass cliff, in addition to what has already been described in the current literature: Women can, in terms of careers, willingly become obstacles to women managers. The "Queen Bee Syndrome", in particular, can explain this situation (Staines, Tavris, and Jayaratne, 1974), in which women who see female manager candidates as threats or obstacles to their own careers tend to support these candidates as better managers than they actually are during difficult/challenging times, thus causing these female manager candidates to be appointed to the relevant positions under more disadvantageous conditions. In other words, women may themselves push female manager candidates towards the glass cliff. The reasons (glass ceiling) that prevent women from becoming upper level manager are lack of role models, gender discrimination, lack of supportive networks and queen bee syndrome in the positive performance periods of corporations. The concept of glass cliff is different from glass ceiling because it means appointment women into upper level management position in negative performance periods of corporations. Glass cliff concept refer to fraudulent positions in which women are appointed to move away from their career goals, to cause them experience stress and to declare them responsible for failure, not because of their competence or successful (Yıldız et al., 2016: 1132). Women as well as men push women glass cliff. Women expecially drug women abyss assigning them upper level managers position because of jealousy in precarious situation of corporations. This may be explained by queen bee syndrome. Therefore it can be say that glass cliff is not only a trap set on the side of men but also a trap set up by women (queen bee syndrome) in negative financial performance periods. If we look at this finding from another perspective, being an upper level executive is important for women's career and thus women can see risky and precarious positions as opportunities and prefer the positions regardless of negative performance (Discussion 3).
In addition, while in positive times, women are led to the glass ceiling mainly by men, this situation changes during negative times, when women are largely responsible for pushing other women towards the glass cliff. As a result, both the glass ceiling and the glass cliff come across as significant obstacles in women's careers. Unlike women don't want women to be senior managers in the positive performance period (glass ceiling), they want women to be senior managers in the negative performance period (glass cliff) because of envy or queen bee syndrome.

\section{Implications}

Considering all of the contextual fundamentals, it can be suggested that the glass cliff phenomenon, as coined by psychologists Ryan and Haslam in the United Kingdom, where the level of individualism and masculinity is high, may not be valid for Turkey, a country where the level of individualism and masculinity is relatively low. The association of women with good crisis management skills and better overall management (think crisis-think female) skills is a stereotypical perception, as is the assumption that a manager should be male under normal circumstances (think manager-think male) (Bruckmüller et al., 2014: 21). In this study, which may pioneer further studies regarding the glass cliff phenomenon within the cultural context, it has been determined that the glass cliff was not valid for the manager respondent groups in Turkey, a country where the level of femininity is high.

\section{Limitations and future research opportunities}

In prospective studies, whether or not the female managers who have broken through the glass ceiling are actually appointed to senior positions in times of crisis, and thus exposed to the glass cliff, could be investigated for different sample groups. Furthermore, records of manager appointments in public and private companies in previous years (male or female), and the periods of these promotions (positive or negative) could be examined by making use of secondary resources in prospective studies. Another research proposal would be to investigate glass cliff perception using sector-based primary data, so as to determine in which sectors female managers are exposed to the glass cliff, and to identify the impact of dimensions such as ability, leadership and trust in being exposed to the glass cliff through experimental studies or surveys. Moreover, different dimensions of the glass cliff (generosity, honesty) could be addressed, and the validity of the concept could be investigated in 
different cultures. The glass cliff phenomenon may be also examined on the basis of ethnic discrimination, as well gender discrimination. Through secondary data, a relationship may be also established between organizational performance (ROA, ROE, Tobin Q) and the number of women on the board.

\section{CONCLUSION}

This research, which was conducted on a study sample of managers is the first study to introduce, theoretically and empirically, the concept of the glass cliff in Turkey. The above-mentioned findings reveal that the glass cliff phenomenon is not supported in these samples. The problem of leading women into risky positions by appointing them to upper management in times of downturn in the company, which is a career barrier that has been expressed in second-wave feminist theories, has not been observed in these samples. This outcome can be attributed to the cultural background of Turkey, namely, the masculinity-femininity aspects of the culture, and also in terms of the Queen Bee Syndrome. 


\section{References}

Adams, S.M., Gupta, A. and Leeth, J.D. (2009), "Are Female Executives Over-Represented in Precarious Leadership Positions?", British Journal of Management, 20: 1-12.

Ak Kurt, D. (2011), "Glass Cliff in Relationship to Hostile and Benevolent Sexism", The Degree of Master of Science in The Department of Psychology, Middle East Technical University, Ankara.

Alican, A. (2007), Kamu Memur Sendikalarında Çalışan Yönetici Kadınlar, SDÜ Yüksek Lisans Tezi, Isparta.

Ashby, J., Ryan, M.K. and Haslam, S.A. (2007),"Legal Work and The Glass Cliff:Evidence that Women Are Preferentially Selected to Lead Problematic Cases",William \& Mary Journal Women and The Law", 13(3): 775-793.

Başak, S. (2013), Toplumsal Cinsiyet (Gender), Editörler: I. Çapçıoğlu ve H. Beşirli, Sosyolojiye Giriş, Grafiker Yayınları, Ankara.

Broadbridge, A., and Simpson, R. (2011), 25 Years On: "Reflecting on the Past and Looking to Future in Gender and Management Research", British Journal of Management, 22, 470-483.

Budig, M.J. (2002), "Male Advantage and the Gender Composition of Jobs: Who Rides the Glass Escalator", Social Problems, 49(2): 258-272.

Bruckmüller, S., and Branscombe, N.R. (2010), "The Glass Cliff: When and Why Women are Selected as Leader in Crisis Contexts", British Journal of Psychology, 49(3): 433-451.

Bruckmüller, S., Ryan, M.K., Rink, F. and Haslam, S.A. (2014), "Beyond The Glass Ceiling: The Glass Cliff and Its Lessons for Organizational Policy, Social Issue and Policy Review, 8(1): 202-232.

Chambers, K. (2011), "The Glass Cliff: The Contribution of Social Identity and Gender Stereotypes in Preceding Leadership Preference and Trust", Master of Art in Psychology, Carleton University, Canada.

Cook, A. and Glass, C. (2013), "Glass Cliff and Organizational Saviors: Barriers to Minority Leadership in Work Organizations?", Society for the Study of Social Problems, 60(2): 168-187.

Dzanic, L. (2009), "The Role of Women in Business: The Case of Bosnia and Herzegovina", Diploma Thesis, University of Ljubljana Faculty of Economics, Bosnia and Herzegovina.

Eagly, A.H. and Carli, L.L. (2007). "Through the Labyrinth: The Truth About How Women Become Leaders",
MA: Harvard Business School Press, 1-5,[Erişim: 10.11.2015, https://www.google.com.tr].

Giddens, A. (2012), Sosyoloji, Çeviren: İsmail Yılmaz, Cinsellik ve Toplumsal Cinsiyet (12. bölüm), Kırmızı Yayınları, İstanbul.

Hair, J., Anderson, R. E., Tatham, R. L. and Black, W. C. (1995), Multivariate Data Analysis, 4th ed. Prentice Hall, New Jersey.

Haslam, S.A. and Ryan, M.K. (2008), "The Road to Glass Cliff: Differences in the Perceived Suitability of Men and Women for Leadership Positions in Succeedings and Failing Organizations", Leadership Quarterly: $1-56$.

Haslam, S.A, Ryan, M.K., Kulich, C., Trojanowski, G. and Atkins,C. (2010), "Investing with Prejudice: The Relationship Between Women's Presence on Company Boards and Objective and Subjective Measures of Company Performance, British Journal of Management, 21 (2): 484-497.

Hofstede, G., Hofstede, G. J., and Minkov, M. (2010), Cultures and Organizations: Software of the Mind, Third Edition, New York, NY: McGraw-Hill.

http://www.ilo.org/ankara/conventions-ratified-by-turkey/WCMS_377248/lang--tr/index.htm, Access Date: 23.03.2016.

https://www.tbmm.gov.tr/anayasa/anayasa82.htm, Access Date: 15.05.2016

https://www.tbmm.gov.tr/kanunlar/k4857.html, Access Date: 15.05.2016

Hunt-Earle, K. (2012), Falling Over a Glass Cliff: a Study of the Recruitment of Women to Leadership Roles in Troubled Enterprises, Global Business and Organizational Excellence, 31 (5): 44-53.

Judge, E. (2003), "Women on Board: Help or Hindrance?", The Times, (www.thetimes.co.uk, Erişim Tarihi: 09.05.2016).

Kanter, R. M. (1977), "Some Effects of Proportions on Group Life: Skewed sex ratios and responses to token women". American Journal of Sociology, 82: 965-990.

Kulich, C., Ryan, M.K. and Haslam, S.A. (2014), "The Political Glass Cliff: Understanding How Seat Selection Contributes to the Under Performance of Ethnic Minority Candidates", Politics Research Quarterly, 67(1):84-95

Lamsa, A.M., Jyrkinen, M., and Heikkien, S. (2012), Women in Managerial Careers, Editor. Pucetaite, R. Cases 
in Organizational Ethics, Vilnius University Press, Lithuania: 4-16.

Mulcahy, M. and Linehan, C. (2014), "Females and Precarious Board Positions: Further Evidence of the Glass Cliff", British Journal of Management, 25 (3): 425-438.

Nunnaly, J. C., (1978), Psychometric theory ( $\left.2^{\text {nd }} e d.\right)$. McGraw-Hill, New York.

Robbins, s.P., and Judge, T.A. (2013), Organizational Behavior ( $14^{\text {th }}$ ed.). Pearson, New Jersey.

Ryan, M.K., and Haslam, S.A. (2005), "The Glass Cliff: Evidence that Women are Over-Represented in Precarious Leadership", British Journal of Management, (16): 81-90.

Ryan, M. K., and Haslam, S. A., (2006), "The Glass Cliff: The Stress of Working on the Edge" European Business Forum, (27): 42-47.

Ryan, M.K., and Haslam, S.A. (2007), "The Glass Cliff: Exploring The Dynamics Surrounding The Appointment of Women to Precarious Leadership Positions", Academy of Management Review, 32(2): 549-572.

Ryan, M.K., Haslam, S.A. and Postmes, T. (2007), "Reactions to Glass Cliff: Gender Differences in The Explanations for The Precariousness of Women's Leadership Positions", Journal of Organizational Change Management, 20(2): 182-197

Ryan, M.K. and Haslam, S.A. (2009), "Glass Cliffs Are Not So Easily Scaled: On The Precariousness of Female CEO's Positions", British Journal of Management, (20): 13-16.

Ryan, M.K., Haslam, S.A. and Kulich, C. (2010), "Politics and The Glass Cliff: Evidence that Women are Preferentially Selected to Contest Hard-to-Win Seats", Psychology of Women Quarterly, 34(1): 56-64.
Ryan, M.K., Haslam, S.A., Hersby, M.T. and Bongiorno, R. (2011), "Think Crisis -Think Female: The Glass Cliff and Contextual Variation in The Manager -Think Male Stereotype", Journal Of Applied Psychology, 96(3): 470-484.

Sabharwal, M. (2013), "From Glass Ceiling to Glass Cliff: Woman in Senior Executive Service", Journal of Public Administration Research and Theory, 25: 399-426.

Schein, V. E. (1973), “The Relationship Between Sex Role Stereotypes And Requisite Management Characteristics", Journal of Applied Psychology, 57: 95-100.

Schein, V. E. (1975), "The Relationship Between Sex Role Stereotypes And Requisite Management Characteristics Among Female Managers", Journal of Applied Psychology, 60: 340-344.

Sekaran, U. (1992), Research Methods for Business: A Skill Building Approach, Second Edition, John Wiley \& Sons., New York.

Staines, G., Tavris, C. and Jayaratne, T. E. (1974), "The queen bee syndrome". Psychology Today, 7(8): 55-60.

Uyar, E. (2011), "The Glass Cliff: Differences in Perceived Suitability and Leadership Ability of Men and Women for Leadership Positions in High and Poor Performing Companies", The Degree of Master Business of Business Administration in The Department of Business Administration, Middle East Technical University, Ankara

Williams, C.L. (1992), "The Glass Escalator: Hidden Advantages for Men in the 'Female' Professions", Social Problems, 39(3): 253-257.

Yıldız, S., Alhas, F., Sakal, Ö. and Yıldız, H. (2016). "Cam Uçurum: Kadın Yöneticiler Cam Tavanı Ne Zaman Aşar?", Ankara Üniversitesi SBF Dergisi, 71 (4): 1119-1146.

www.hofstede-insight.com/country/turkey, Erişim tarihi: 16.03.2019. 